\title{
The Role of UNESCO Global Geoparks in Promoting Geosciences Education for Sustainability
}

\author{
Maria Manuela Catana ${ }^{1,2}$ (1) $\cdot$ José B. Brilha ${ }^{2}$ (1) \\ Received: 17 April 2019 / Accepted: 7 January 2020 \\ (C) The European Association for Conservation of the Geological Heritage 2020
}

\begin{abstract}
Following the establishment in 2000 of the first geoparks, the role of UNESCO Global Geoparks (UGGps) in geoscience education for sustainability needs to be characterized and understood. This is particularly relevant because education is one of the three main pillars of UGGps. In fact, UNESCO Global Geoparks are excellent opportunities to assist schools as outdoor classrooms and to be incubators of sustainable development, sustainable lifestyles, the appreciation of natural and cultural diversity, and the promotion of peace. For these reasons, UGGps are also effective strategies for the promotion of the seventeen United Nations Sustainable Development Goals (Agenda 2030). The analysis of the data obtained with an online questionnaire answered by seventy-three UGGps from thirty-five countries around the world allowed the characterization of the role played by geoparks in the promotion of geosciences education for sustainability through educational programs specifically addressed to the school community. This characterization will support the establishment of proposals of new methods, strategies, and resources to encourage the development of new educational programs in UGGps.
\end{abstract}

Keywords Geosciences education · Sustainable development · Formal education · Geoparks · Geoheritage

\section{Introduction}

UNESCO Global Geoparks (UGGps) are territories where sites and landscapes of international geological relevance are managed on the basis of a holistic concept of conservation, education, and sustainable development (UNESCO 2016). Having started in Europe by the end of the 1990s (Henriques and Brilha 2017), there are 147 UGGps distributed by 41 countries worldwide (numbers as for November 2019).

Education for sustainability is one of the three main pillars of any geopark, together with geoconservation and geotourism (McKeever and Zouros 2005; Zouros 2004). All UGGps must develop and promote educational activities for people of all ages, in order to raise awareness of geological heritage and its relationships with other aspects of natural,

Maria Manuela Catana

mmscatana@gmail.com

1 Naturtejo UNESCO Global Geopark, Educative Service of the Municipality of Idanha-a-Nova, Centro Cultural Raiano, Avenida Joaquim Morão, 6060-101 Idanha-a-Nova, Portugal

2 Institute of Earth Sciences, Pole of the University of Minho, Braga, Portugal cultural, and intangible heritage. It is not possible to guarantee the conservation of geoheritage if society in general does not understand the importance of geodiversity and geoheritage (Brilha et al. 2018; Gray 2018; Reynard and Brilha 2018). The main objective of geoconservation is the management of important elements of geodiversity (minerals, rocks, fossils, soils, landforms, and active geological processes) with exceptional scientific, educational and tourist values (Burek and Prosser 2008; Henriques et al. 2011). Thus, policies and educational actions concerning geoconservation are very important, either in the school context (formal education) or addressed to the general public (non-formal education) (Catana 2008; Van Loon 2008). Educational strategies in geoparks should be supported by partnerships from schools, universities, and local councils. These strategies should include training activities for local teachers and students, as well as events to raise public awareness on natural and cultural heritage. All geoparks should embrace the responsibility of being active promoters of geosciences education for sustainable development addressed to all members of the public.

The Man and Biosphere Programme, the Convention Concerning the Protection of the World Cultural and Natural Heritage, and, since 2015, UGGps, are three UNESCO mechanisms to promote the implementation of the Agenda 2030 for Sustainable Development, adopted by the United Nations, in 
September 2015. The Agenda 2030 comprises seventeen Sustainable Development Goals (SDGs) and one hundred and sixty-nine targets, which are deeply embedded in the economic, social, and environmental dimensions of sustainable development (McKeever 2018). Their stated aims are to eradicate global poverty, end unsustainable consumption patterns, and facilitate sustained and inclusive economic growth, social development, and environmental protection over a 15 -year timeframe (United Nations 2015). Achieving the SDGs by 2030 will require many communities and sectors to engage actively, including the geoscientific one. Gill (2017) relates the seventeen SDGs to eleven key aspects of geology: agrogeology, climate change, energy, engineering geology, geohazards, geoheritage and geotourism, hydrogeology and contaminant geology, mineral and rock resources, geological capacity building, geosciences education, and a miscellaneous category. Therefore, geoscientists have an important task in helping society to achieve the SDGs. Effective engagement should draw upon geologists within civil society, the public and private sectors (Bitar 2004; Cordani 2000; Gill 2017). Thus, UGGps are perfect laboratories to implement and contribute to achieving the SDGs, as shown in the brochure "UNESCO Global Geoparks contributing to the Sustainable Development Goals - Celebrating Earth Heritage, Sustaining local Communities" (UNESCO 2016). The results of a survey showed that the SDG number four - quality education - is the most important goal for sustaining UGGps relevant projects (Silva and Weber 2018).

Regarding formal education, geoparks promote numerous activities and develop educational resources for students and teachers (e.g., field trips, geology clubs, educational programs and resources adapted to different school levels, teaching kits). Geoparks also provide non-formal education for adults and some also provide specific training addressed to local people.

In order to understand geoparks' role in geosciences education for sustainability, it is necessary to characterize the educational programs and activities promoted by geoparks. This was the main aim of the work presented in this paper.

\section{Methods}

The main tool used to collect data for this research was a questionnaire specifically prepared and made available online (Google Forms $($ ) ), aiming to provide a current picture of how UGGps are addressing the issue of formal education in geosciences and its relationship with sustainable development.

The work started with an extensive bibliographical research about geoscience literacy, education for sustainability, and the relationship between geosciences education and education for sustainability. Particular attention was given to best practices on the elaboration of questionnaires and data analysis related with geosciences education and environmental education (e.g., Alves et al. 2013; Guerra et al. 2008; Kerlin et al. 2015; King 2015a, b; Macedo 2006; Schmidt et al. 2010a, b).

The questionnaire was designed in order to obtain data from five key questions:

- How are geoparks organized and prepared concerning the promotion of formal education?

- Who is the main audience for educational activities promoted by geoparks?

- What types of activities and educational resources exist in geoparks?

- What are the topics addressed in educational activities and how is the issue of sustainability addressed?

- How is the promotion and evaluation of these activities carried out?

A pilot version of the questionnaire was sent to ten geoparks in eight countries (two both in Portugal and Spain, and one in each of the following countries: Canada, Mexico, China, Slovenia, Iran, and Romania). During July and August 2017, eight geoparks answered the questionnaire; based on these answers, some adjustments were made to the questionnaire. The final questionnaire constituted by eighty-seven questions and sub-questions is organized in seven parts:

(1) Identification of the UNESCO Global Geopark;

(2) Educational geopark team;

(3) Educational project;

(4) Working methods;

(5) Educational resources and target audience;

(6) Partnerships;

(7) Promotion and evaluation strategy.

The questionnaire includes closed and open questions. Closed questions are dichotomous, multiple choice, or Likert scale (to select one of five possible options). Open questions are the quick-response type. At the end of the questionnaire, there is an open field allowing free comments and observations.

The final version of the questionnaire was sent in September 2017, by e-mail, to one hundred twenty-seven UNESCO Global Geoparks (the total number of geoparks existing at that time), together with a text explaining the context of the research. The scientific and executive coordinators or the leaders of the educational department of geoparks were invited to respond. Until December 2017, seventy-three geoparks from thirty-five countries had replied (57.5\% of the whole set of geoparks). Of these seventy-three geoparks, fifty-three are located in European countries (Austria, Croatia, Cyprus, Czech Republic, Denmark, France, Hungary, Iceland, Italy, Finland, Greece, Germany, Norway, Poland, Portugal, Slovenia, Spain, 
The Netherlands, Turkey, Republic of Ireland, Romania, Slovakia, and the UK) (corresponding to $76 \%$ of all European members), thirteen in Asia (China, Indonesia, Iran, Japan, Malaysia, Republic of Korea, Vietnam) (26\%), four in Latin America (Brazil, Mexico, Uruguay) (100\%), two in North America (Canada) (100\%), and one in Africa (Morocco) $(100 \%)$ (Fig. 1). All the four transnational geoparks participated in the study, as well as geoparks located in all the thirty-five countries with UGGps in September 2017. The data were analyzed using simple statistical treatment.

\section{Results}

The most relevant results and their analysis are presented in this section; the analysis does not necessarily reflect the order of the questions in the questionnaire.

\section{How Are Geoparks Organized and Prepared Concerning the Promotion of Formal Education?}

Only one of the seventy-three geoparks that responded to the questionnaire does not promote educational activities for schools, which is a peculiar situation given the framework of the geopark concept (Fig. 2). Concerning the remaining seventy-two geoparks, forty-five (62\%) have a dedicated educational department; however, in seven of them (10\%), this department is not run by the general management structure of the geopark but rather by a partner organization. Twentyseven geoparks (37\%) do not have a specific educational department but even so they offer activities for schools.

Almost all UGGps with an educational department (fortyfour out of forty-five) have a specific coordinator in this department. Most of these coordinators are women between 41 and 50 years old, with an academic background including geology, biology, or teaching, and holding a permanent position in the geopark. The coordinators that are not part of the geopark's staff usually have a contract with partner institutions, namely universities, municipalities, or local schools. In geoparks without a specific coordinator for educational activities, this task falls into the responsibility of the scientific or executive coordinators of the geopark.

In half of geoparks with an educational department, there are one-two persons working exclusively in the department. These people have a scientific training in geology, teaching, and environmental education, among other disciplines. In six

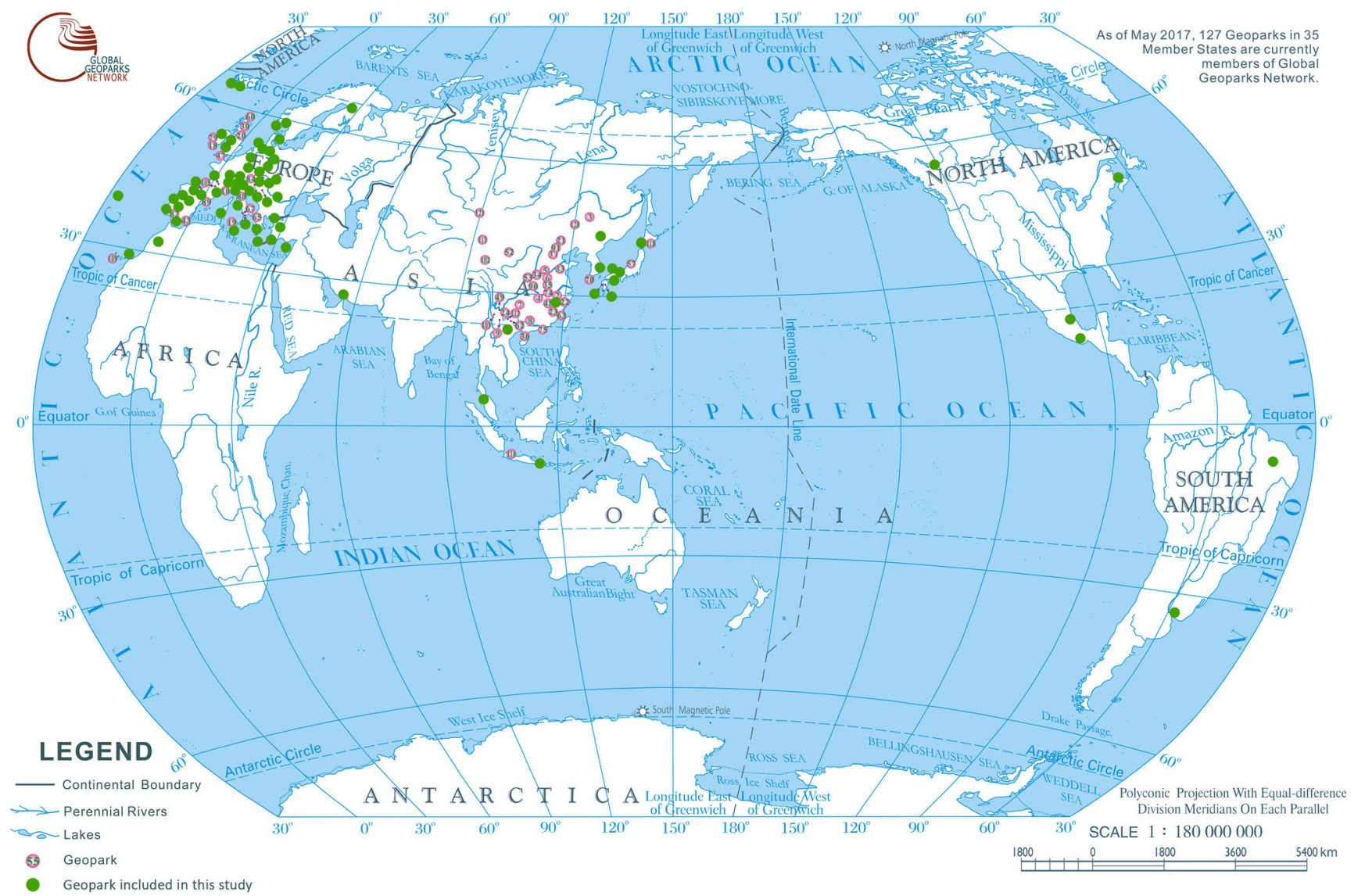

Fig. 1 Worldwide distribution of UNESCO Global Geoparks as of May 2017. The geoparks that have participated in this study are represented with green dots (modified from Chinese Geoparks Network \& GGN Beijing Office, www.global-geoparks.org) 
Fig. 2 Almost all UGGps that have participated in the study offer educational activities for schools, even if they do not have a specific educational department

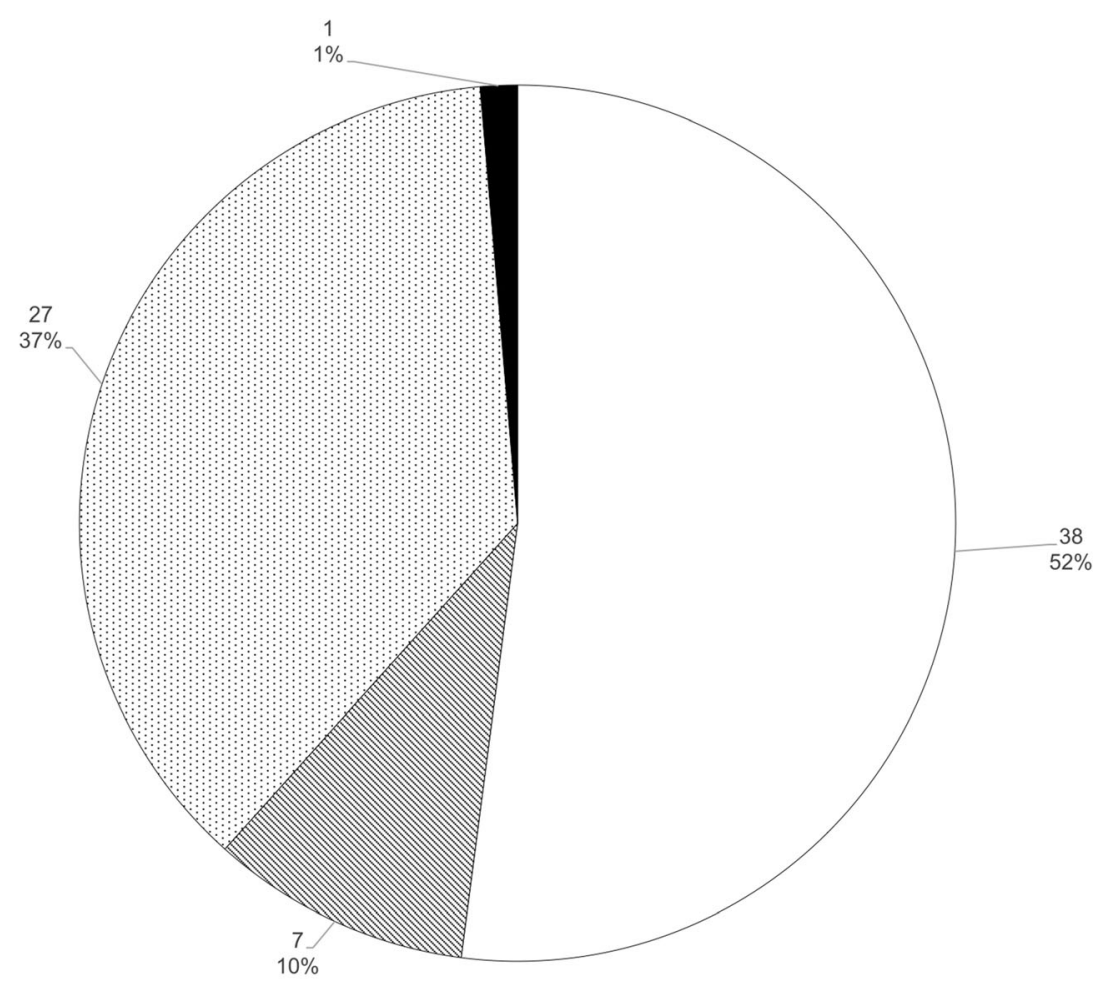

$\square$ The educational department is under the management structure of the geopark $\mathbb{Q}$ The educational department is managed by a geopark partner ๑No educational department but still offer activities for schools

- No educational department and no offer of activites for schools of the geoparks, there are no staff working exclusively in the educational department: they work there only when is needed.

Several geoparks have partnerships to support educational programs such as local schools (sixty-nine geoparks), universities, research or teacher training centers (sixty-two geoparks), local community/local associations (fifty-one geoparks), educational centers/environmental interpretation/ science/museum (forty-seven geoparks), and local administration (thirty-six geoparks).

Most geoparks (63\%) never promoted any educational projects in partnership with other geoparks of their own country but, on the other hand, most geoparks (53\%) have done so with geoparks from other countries.

\section{Who Is the Main Audience for Educational Activities Promoted by Geoparks?}

Not surprisingly, the most frequent users of educational activities are schools ( $92 \%$ of geoparks), in particular students who are 11-12, 13-15, 6-10, and 16-18 years old (in descending order). Only $4 \%$ of the geoparks organize specific educational activities for families and university students. The majority of geoparks $(58 \%)$ receive students from schools from all over the country. Only $15 \%$ of the geoparks work mainly with schools located inside the geopark.

Most geoparks (71\%) do not offer specific activities for students with disabilities or activities aimed at promoting the integration of students with a culture/religion different from the one prevailing in the country (76\%).

Concerning the number of students involved in educational activities, and taking as reference the 2016/2017 school year, $58 \%$ of geoparks report less than one thousand students involved (Fig. 3). For $31 \%$ of geoparks, more than two thousand students were reported. Regarding the number of teachers, less than one hundred teachers were involved in educative programs, for $75 \%$ of geoparks. However, most geoparks stated that they received between one and ten thousand students and teachers since the geopark started to offer educational activities.

\section{What Type of Activities and Educational Resources Exist in Geoparks?}

Almost all geoparks (87\%) have educational activities included in their annual planning and offer schools two possible choices: pre-defined packages of activities or a list of activities 
Fig. 3 Number of students that have participated in educational programs in the 2016/2017 school year

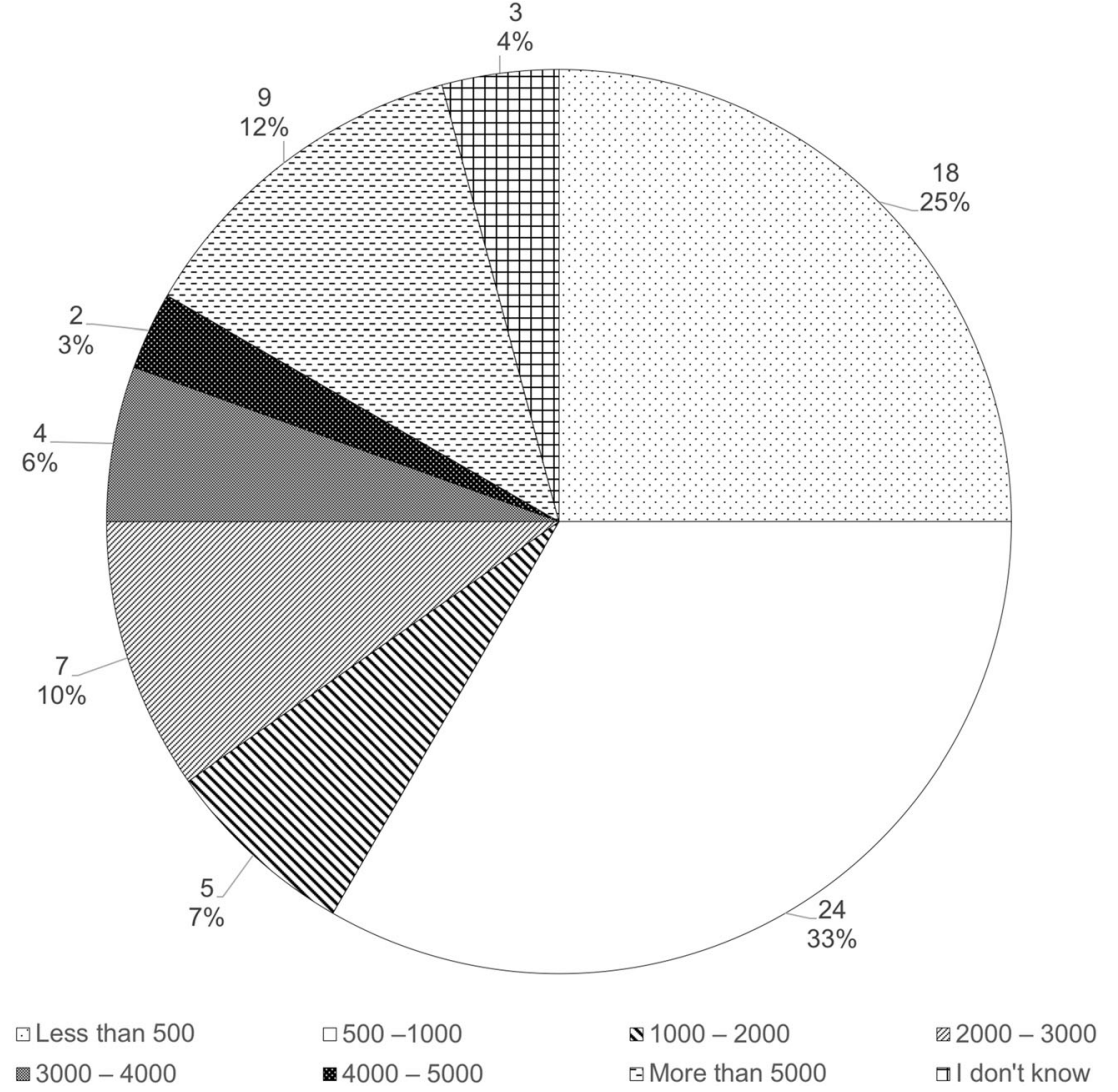

that can be selected according to specific needs. The rest of the geoparks have just one of these choices available. In addition, most geoparks $(82 \%)$ have special educational activities to celebrate commemorative dates (e.g., water day, soil day). Guided fieldtrips are the most common activity proposed to schools, followed by workshops, celebration of thematic dates, and visits to interpretative centers and museums (Fig. 4). Usually, these activities have a half-day duration.

Geoparks also organize activities for teachers, in particular (in descending order): field trips, training courses, workshops, and conferences/seminars.

In most geoparks, educational programs receive less than $30 \%$ of their annual budget. For the remaining ones, funding comes from the local and/or regional administration, sometimes from international programs and, less frequently, from the national administration. In five geoparks, educational programs do not need funding because they are self-sustaining. In fact, in $32 \%$ of the geoparks, educational activities generate a revenue that becomes part of their general budget. Educative activities are free-of-charge for all in twenty-seven geoparks; in the other geoparks, these activities are free only for schools located inside the geopark or, less frequently, the activities need to be fully paid by all.

Geoparks use different types of educational resources to support their educational offer, such as fieldtrips and games (Fig. 5); some of the most common are presentations/documentaries/videos, pedagogical guides, and panels.

\section{What Are the Topics Addressed in Educational Activities and How Is the Issue of Sustainability Addressed?}

Most geoparks (72\%) are in countries where geosciences subjects are taught in the following disciplines as part of preuniversity curriculum: natural sciences (forty-four geoparks), geography (thirty- nine), geology (thirty-one), biology (twenty-five), physical sciences (fifteen), and others (social sciences/history and culture/outdoor education) (eight). The respondents of four geoparks mentioned not knowing if geosciences were taught in their countries.

Educational activities promoted by UGGps are adapted to different school levels in $93 \%$ of the geoparks and to the national curricula of some disciplines (e.g., biology, geology, geography) in $75 \%$ of geoparks. Interdisciplinary activities are offered by $88 \%$ of the geoparks, namely, geosciences/biology, history/culture, nature conservation/protected areas, and environmental education. Activities linking physical education/ natural sciences, geography/natural sciences, and history/ culture are also frequent.

Educational geoscience activities promoted by UGGps include topics of general geology, geodiversity, geological heritage, and geoconservation. In addition, other topics like biodiversity, environmental education/education for sustainability, and history/cultural heritage/traditions are also promoted. 
Fig. 4 Types of educational activities most frequently organized for schools

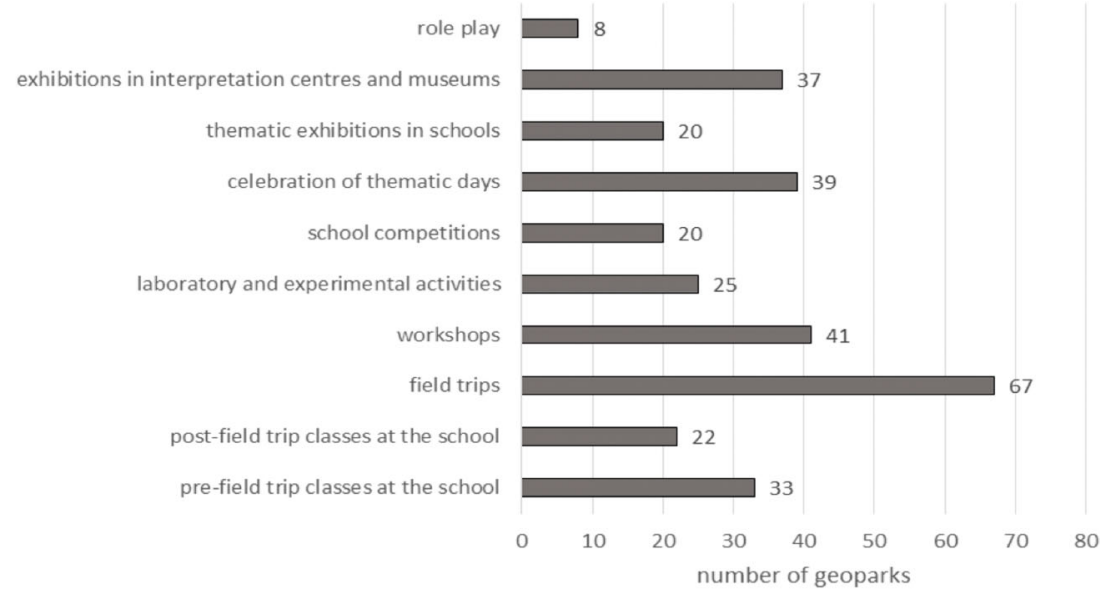

The planning of educational activities takes into account national/regional/local sustainable development projects (e.g., Local Agenda Twenty-one, Agenda Twenty-one for Schools, Eco-Schools Programme) in $68 \%$ of the geoparks. Among the ten aims of geoscience education for sustainability proposed in the questionnaire, the three most frequently selected by geoparks were the following: "sensitizing for the conservation of natural and historical-cultural heritage," "promoting direct contact with local natural environment," and " promoting knowledge of natural and cultural aspects of the geopark."

From the twelve aims concerning the contribution of geosciences for sustainable development also proposed in the questionnaire, the top five used in geoparks' educational activities are "geotourism," "geoconservation," "knowledge about the Earth System," "climate change," "conservation and management of water resources" (Fig. 6).

When considering the seventeen UN Sustainable Development Goals (Agenda 2030), the five that are most addressed in geoparks' educational activities are, in descending order: "four - Quality education," "fifteen Terrestrial ecosystems and biodiversity," "eleven Sustainable cities and communities," "thirteen - Combating climate change," "three - Healthy life" (Fig. 7).

\section{How Is the Promotion and Evaluation of These Activities Carried Out?}

Geoparks use several strategies to advertise their educational programs in schools, namely, direct contact with teachers, the geopark website, edition of a printed or online booklet, email, and newsletter/e-newsletter.

In nine geoparks, the evaluation of educational activities is not implemented. In the other geoparks, meetings are held with the staff involved in the organization of the activities and a satisfaction questionnaire is distributed to teachers and students. In only ten geoparks, students are pre- and post-tested in order to evaluate the evolution of their knowledge (Fig. 8).
Fig. 5 Educational resources used by geoparks to support their educative offer

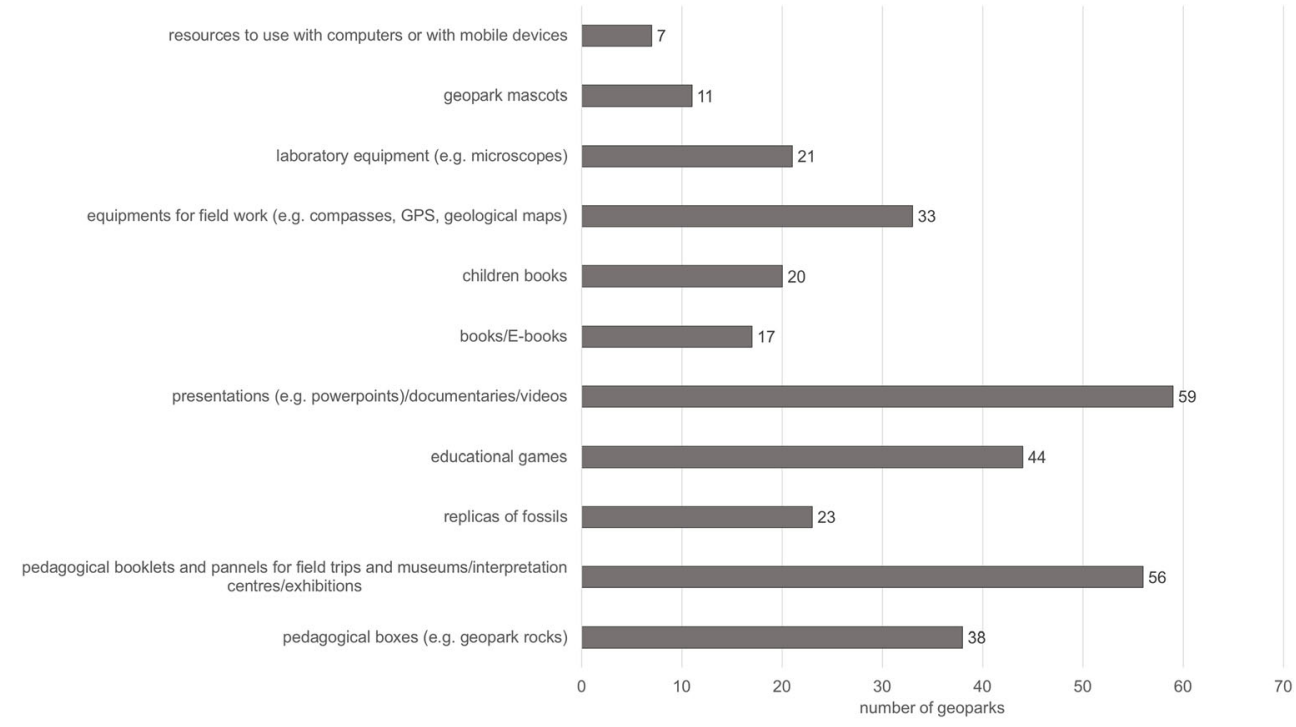


Fig. 6 Contributions of geosciences for the sustainable development used in educational activities

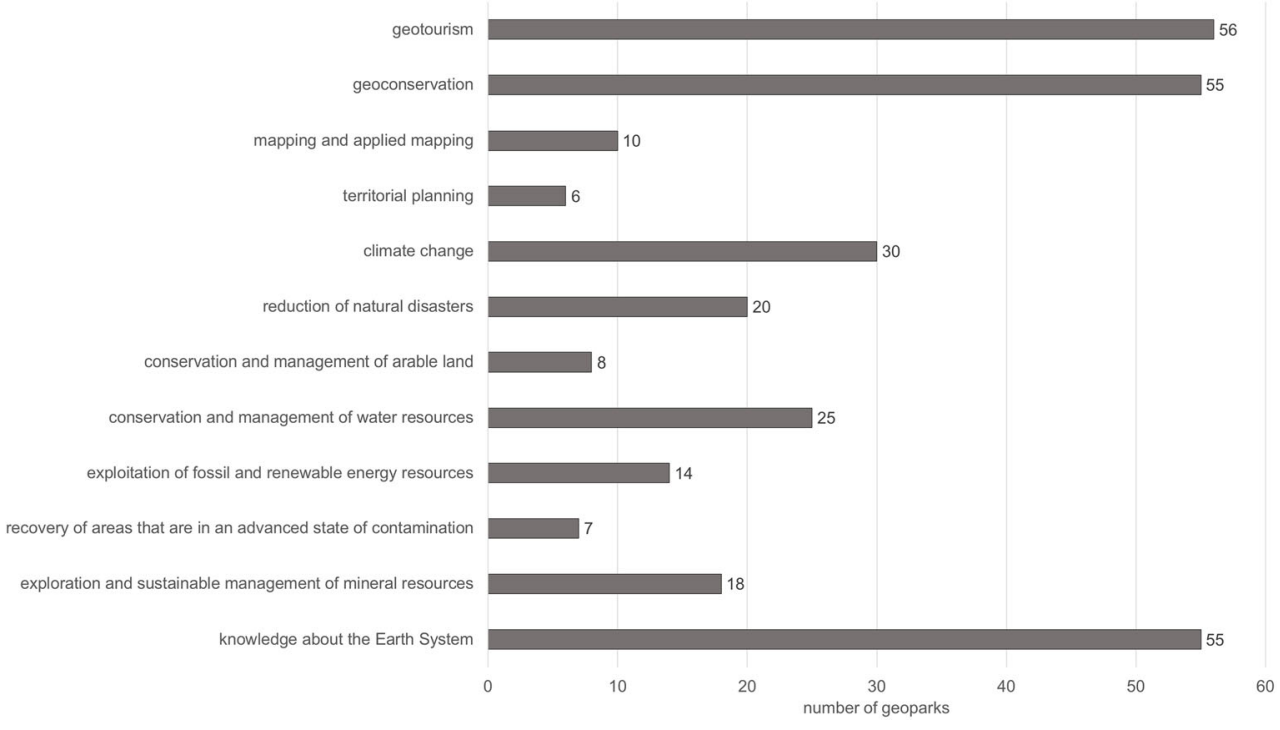

The five major difficulties reported by geoparks in managing and organizing educational programs are reduced funding (forty-seven geoparks), reduced educational resources (twenty-nine geoparks), insufficient promotion of educational activities (twenty-three geoparks), lack of scientific/didactical equipment for field trips and laboratory classes (twenty-two geoparks), few education/interpretation infrastructures and museums (eighteen geoparks).

Geoparks consider as extremely important the increasing of the involvement of teachers of schools located inside the geopark. Another priority is the establishment of a network of schools and an increase of cooperation with other geoparks. Also considered very important is the major involvement of scientific institutions with the geopark.

Most UGGps (68\%) believe that it would be useful to have guidelines for evaluation/analysis criteria for educational programs, and $87 \%$ mention that more educational strategies and resources should be created to be used in UGGps, namely, funding to promote the exchange of students and teachers between different countries, work/holidays camps for students and teachers, educational games, training workshops to promote the exchange of staff working on educational departments of geoparks in different countries, as well as the establishment of a working group in the Global Geoparks Network (GGN) dedicated to the education and production of documentaries/videos.

\section{Discussion}

Based on the analysis of the data obtained from the questionnaire, it became clear that geosciences education for sustainability is in fact one of the backbones of geoparks' action plans. The only geopark that did not report any action
Fig. 7 The SDG (Agenda 2030) most explored in educational activities organized by geoparks

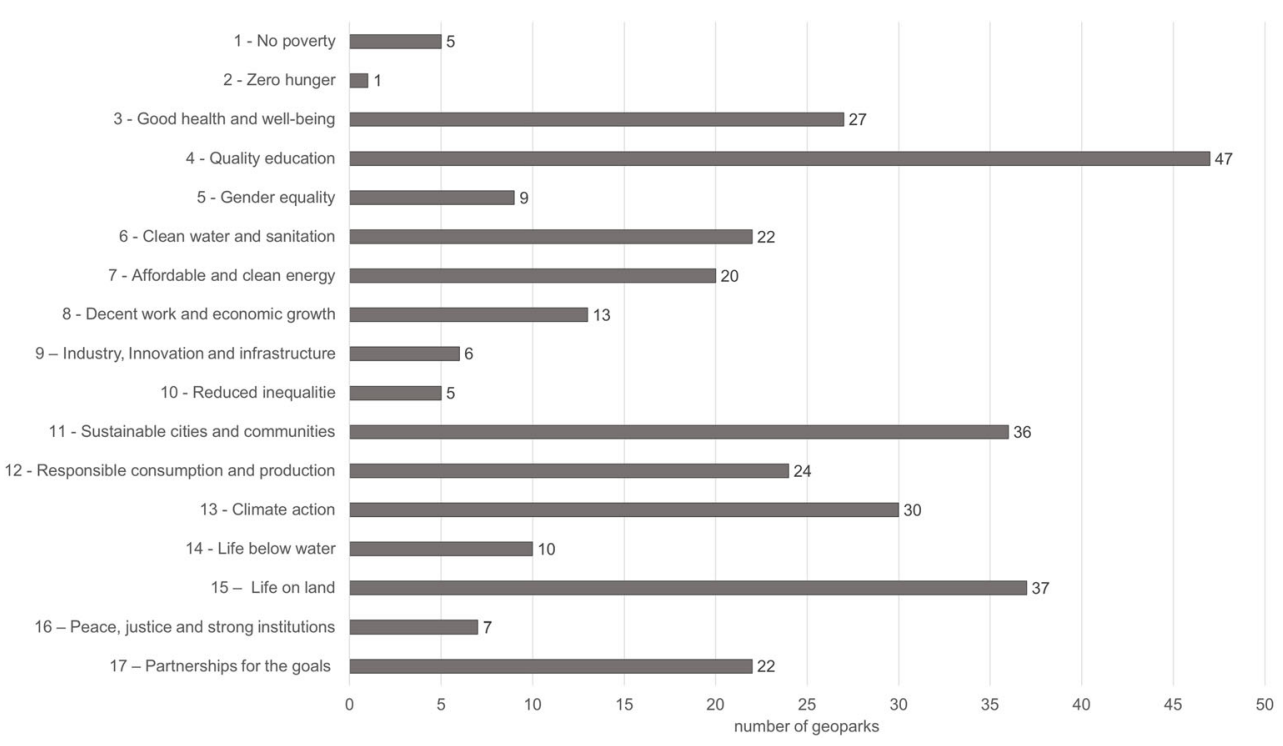


Fig. 8 Strategies/methods to evaluate educational activities

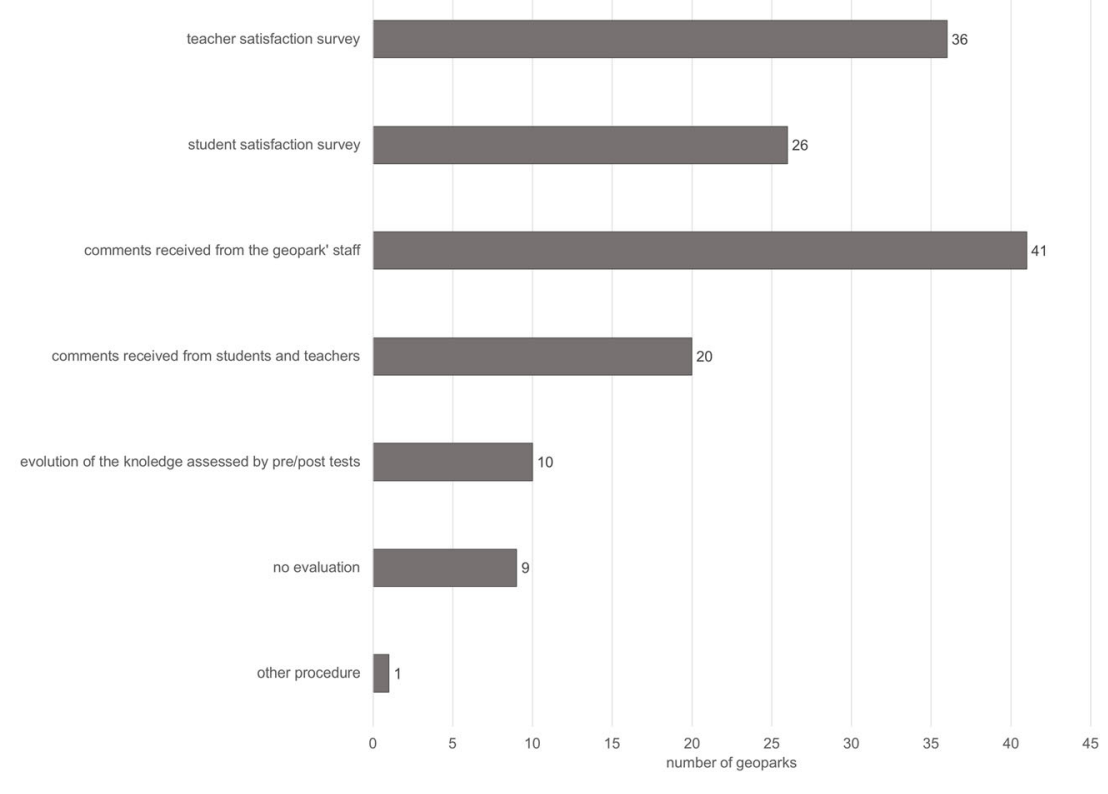

regarding educational programs has a short working experience because it was accepted as a UGGps member the year prior to the completion of the questionnaire. The analysis of the results of the questionnaires presented in the last section allows a set of reflections, presented below.

(1) Educational activities in UGGps are organized by their educational departments. In geoparks with no specific educational department, the scientific or the executive coordinator of the geopark is usually the one responsible for educational activities. In both situations, the responsible person has a scientific background including geology and has a permanent contract with the management structure of the geopark. Regarding the staff working in educational programs, usually there are one or two professionals in each geopark with a scientific background on geology, since geodiversity is the key topic on which most educational programs are built. The partner organizations that collaborate with geoparks to implement educational activities are mostly local, something that is understandable since geoparks should foster synergies in their own territories. Networking of geoparks related to educational projects usually involves geoparks from different countries probably because the majority of these projects receive funding from programs that aim to promote the existence of relations between countries. This is more common in Europe, for instance, with the Interreg programme.

(2) Most schools that have already participate in educational activities are located inside or near the geopark which is understandable due to the fact that the longer the distance, the more complicated are the logistics for schools and the higher the cost of transportation. As for the number of students and teachers who have participated in educational activities promoted by geoparks during the 2016/2017 school year, most geoparks received less than one thousand students and less than one hundred teachers. Most geoparks were visited by one to ten thousand students and teachers since the geopark has started to offer educational activities, which of course is very variable depending on when each geopark began operating. Ages of the students most frequently are 6-18 years old, which means that geoparks are covering the full possible spectrum between primary and secondary schools. There are, however, two aspects that are not yet fully addressed by most geoparks: the offer of specific activities for students with disabilities and activities aimed at the integration of students with culture/religion different from the one prevailing in the geopark.

(3) Educational activities generally have annual planning and are available in pre-defined packages and "à-lacarte.” Environmental theme days are usually celebrated (water day, soil day, etc.). The most common activities available for students are field trips, workshops, celebration of theme days, exhibitions in interpretation centers and museums, and pre-field classes at the school. Concerning the duration of the activities, the most common are those lasting half-day. Regarding activities particularly addressed to teachers, the most frequent are field trips, followed by training courses. The funding for educational programs comes from the geopark's budget, followed by the local administration and by the regional/state administration. Only five geoparks have stated that their educational programs do not require 
funding because they are self-sustaining. The annual investments spent on educational activities usually do not exceed $30 \%$ of the geopark's annual budget. In most geoparks, educational programs do not constitute a revenue source for their management because they are free-of-charge, especially for schools located inside the geopark.

(4) Most geoparks promote activities adapted to different school levels and to some disciplines of the national curricula (biology, geology, geography). They also promote interdisciplinary activities highlighting the relation between geosciences and biology, history and culture, nature conservation and protected areas, and environmental education. Geological themes usually addressed by geoparks are based on concepts/processes of general geology, geodiversity, geological heritage, and geoconservation. Geoparks are effectively contributing to the raising of awareness for the protection and conservation of the natural and historical-cultural heritage in their territories and also take into account national/regional/local projects or strategies for sustainable development (e.g., Local Agenda Twenty one, Agenda Twenty one for Schools, Eco-Schools Programme). Of the seventeen SDGs (Agenda 2030), the most explored in educational activities are (in descending order) "four quality education," "fifteen - terrestrial ecosystems and biodiversity," "eleven - sustainable cities and communities," "thirteen - combating climate change," "three healthy life." The theme "climate change" is a topic addressed by many geoparks, following the Declaration of Shimabara approved during the 5th International Geoparks Conference held in Japan, in 2012. The type of educational resources used by geoparks was also under analysis. The most common are presentations/documentaries/videos. The direct contact with teachers is the most common strategy for advertising educational programs in schools.

(5) Concerning the evaluation of the educative offer, only nine geoparks do not evaluate their educational activities. Most geoparks promote evaluation meetings with the staff involved in the organization of these activities and concluded that reduced funding is the greatest difficulty concerning the management and organization of activities. When considering what is needed to improve the actions related to geosciences education for sustainability, geoparks have selected as extremely important the increasing of the involvement of teachers of the geopark's schools, the establishment of a network of partner schools, and an increase of cooperation with other geoparks. All these requisites are under the responsibility of the geopark's coordinators and do not demand significant funding resources. Finally, the majority of geoparks mention the need for guidelines for evaluating educational programs and the existence of more educational strategies/resources to be used in UGGps.

\section{Final Remarks}

The analysis of the online questionnaires returned by seventy-three UGGps allowed to characterize and to better understand the important role of UNESCO Global Geoparks in the promotion of geosciences education for sustainability addressed to the school community. Education is actually one of the pillars of UGGps, and for this reason, most geoparks have a specific educational department in which spends about one-third of the annual budget of the geopark. The results of this work are now being used to support proposals of innovative guidelines and resources to be applied in UGGps, following the expectations of most of the geoparks that were involved in this study. These guidelines will include recommendations such as (i) the staff involved on educational programs must have specific training on geology education; (ii) the educational programs should be considered as a complement of formal education; (iii) educational programs should be focused on topics and themes related with the national curricula and adapted to different schools levels; (iv) the educational programs may benefit from the involvement of key partners, namely, schools, universities, teachers training centers, museums, interpretative and environmental education centers, or outdoor adventure businesses.

Naturtejo UNESCO Global Geopark (Portugal) is being used as a case study to develop the new guidelines and educational resources. After the conclusion of this research, the results and products will be distributed to all the UGGps. During the last European Geoparks Conference held at Seville in September 2019, a preliminary version of the results obtained with this questionnaire was already presented to the geoparks community (Catana and Brilha 2019).

Recently, the Global Geoparks Network has created two new working groups: one dedicated to "Education" and another to "Sustainable Development Goals." It is expected that future outcomes of these two working groups will also significantly contribute to the improvement of education in UGGps.

Acknowledgments We want to acknowledge the coordinators and staff of the 73 UGGps that answered the questionnaire and allowed this study to take place.

Funding Information This work is co-funded by the European Union through the European Regional Development Fund, based on COMPETE 2020 (Programa Operacional da Competitividade e Internacionalização), project ICT (UID/GEO/04683/2013) with reference POCI-01-0145-FEDER-007690, and national funds provided by Fundação para a Ciência e Tecnologia. 


\section{References}

Alves J, Carvalho S, Meira-Cartea PÁ, Azeiteiro UM (2013) Diagnóstico sobre equipamentos para a educação ambiental no distrito de Lisboa. Aspectos biofísicos e socioculturais nos projectos educativos. Captar: Ciência e ambiente para todos 4(1):72-91 https://repositorioaberto. uab.pt/bitstream/10400.2/2831/1/Diagn\%C3\%B3stico\%20sobre\% 20Equipamentos\%20para\%20a\%20Educa\%C3\%A7\%C3\%A3o.pdf

Bitar OY (2004) Meio ambiente \& geologia. Senac, São Paulo

Brilha JB, Gray M, Pereira D, Pereira P (2018) Geodiversity: an integrative review as a contribution to the sustainable management of the whole of nature. Environ Sci Pol 86:19-28

Burek CV, Prosser CD (eds) (2008) The history of geoconservation. Geological Society. Special Publications, London

Catana MM (2008) Os Programas Educativos do Geopark Naturtejo: Ensinar e aprender geociências em rotas, geomonumentos, museus e na escola. In: Neto de Carvalho C, Rodrigues J, Jacinto A (eds) Livro das XVIII Jornadas sobre a função Social do Museu Geoturismo \& desenvolvimento local, Câmara Municipal de Idanha-a-Nova, Idanha-a-Nova, pp 291-307

Catana MM, Brilha JB (2019) UNESCO Global Geoparks and formal education: what is being done? Abstracts of the $15^{\text {th }}$ European Geoparks Conference, Sevilla, Spain, pp 52

Cordani UG (2000) The role of the earth sciences in a sustainable world. Episodes 23(3):156-162

Gill JC (2017) Geology and the sustainable development goals. Episodes 40(1):70-76

Gray M (2018) The confused position of the geosciences within the "Natural Capital" and "Ecosystem Services". Approach Ecosyst Serv 34:106-112

Guerra J, Schmidt L, Nave JG (2008) Educação ambiental em Portugal: Fomentando uma Cidadania responsável. VI Congresso Português de Sociologia - Mundos Sociais: Saberes e Práticas, Lisboa http:// historico.aps.pt/vicongresso/pdfs/681.pdf. Accessed 21 January 2017

Henriques MH, Brilha JB (2017) UNESCO Global Geoparks: a strategy towards global understanding and sustainability. Episodes 40(4): 349-355

Henriques MH, Reis RP, Brilha JB, Mota TS (2011) Geoconservation as an emerging geoscience. Geoheritage 3(2):117-128

Kerlin S, Kacorosky J, Liddicoat K (2015) Status and needs of environmental education related organizations in Wisconsin: Results of the 2014 State-wide Survey. https://www.uwsp.edu/cnr-ap/wcee/ Documents/Survey_Final_Report_January_2015.pdf. Accessed 15 January 2017
King C (2015a) The international geoscience school syllabus and its development. Episodes 38(1):57-74 http://52.172.159.94/index. php/epi/article/view/63810/49820

King C (2015b) The need for an international geoscience school syllabus: its development and publication. Sci Educ Int 26(4):420-438 http:/ www.icaseonline.net/sei/december2015/p1.pdf

Macedo P (ed) (2006) Futuro Sustentável - Diagnóstico de Ambiente do Grande Porto - Educação Ambiental/Educação para o Desenvolvimento Sustentável. Versão Final para Consulta Pública. http://portal.amp.pt/media/documents/2015/06/08/diagnostico educacao fs i.pdf. Accessed 15 January 2017

McKeever P (2018) UNESCO Global Geoparks and Agenda 2030. Proceedings of the 8th International Conference on UGGps: Geoparks and Sustainable Development. Adamello Brenta UNESCO Global Geopark, Madonna di Campiglio, pp 22

McKeever P, Zouros N (2005) Geoparks: celebrating earth heritage, sustaining local communities. Episodes 28(4):274-278

Reynard E, Brilha JB (eds) (2018) Geoheritage: assessment, protection, and management. Elsevier, Chennai

Schmidt L, Nave JG, Guerra J (2010a) Educação Ambiental: Balanço e perspetivas para uma agenda mais sustentável. Imprensa de Ciências Sociais, Lisboa

Schmidt L, Nave JG, Guerra J (2010b) The role of non-scholar organizations in environmental education: a case study from Portugal. Int $\mathrm{J}$ Environ Sustain Dev 9(1/2/3):16-29

Silva E, Weber J (2018) European Global Geoparks: effective contribution for the achievement of the SDGs. Proceedings of the 8th International Conference on UGGps: Geoparks and Sustainable Development Adamello Brenta UNESCO Global Geopark, Madonna di Campiglio, pp 297

UNESCO (2016) UNESCO Global Geoparks contributing to the sustainable development goals - celebrating earth heritage, sustaining local communities. UNESCO Global Geoparks. Paris. http://unesdoc. unesco.org/images/0024/002477/247741E.pdf. Accessed 15 January 2017

UNITED NATIONS (2015) Transforming our world: the 2030 agenda for sustainable development. United Nations, Geneva https:// sustainabledevelopment.un.org/content/documents/21252030\% 20Agenda\%20for\%20Sustainable\%20Development\%20web.pdf. Accessed 21 January 2017

Van Loon AJ (2008) Geological education of the future. Earth Sci Rev 86: $247-254$

Zouros N (2004) The European Geoparks network. Geological heritage protection and local development. Episodes 27(3):165-171 